\title{
Predicting decadal trends in cloud droplet number concentration using reanalysis and satellite data
}

\author{
Daniel T. McCoy ${ }^{1}$, Frida A.-M. Bender ${ }^{2}$, Daniel P. Grosvenor ${ }^{1,5}$, Johannes K. Mohrmann ${ }^{3}$, Dennis L. Hartmann ${ }^{3}$, \\ Robert Wood $^{3}$, and Paul R. Field ${ }^{1,4}$ \\ ${ }^{1}$ School of Earth and Environment, Institute of Climate and Atmospheric Science, University of Leeds, \\ Leeds, LS2 9JT, UK \\ ${ }^{2}$ Department of Meteorology and Bolin Centre for Climate Research, Stockholm University, Stockholm, 106 91, Sweden \\ ${ }^{3}$ Department of Atmospheric Sciences, University of Washington, Seattle, 98195, USA \\ ${ }^{4}$ MetOffice, Exeter, EX1 3PB, UK \\ ${ }^{5}$ National Centre for Atmospheric Science (NCAS), University of Leeds, Leeds, LS2 9JT, UK
}

Correspondence: Daniel T. McCoy (d.t.mccoy@leeds.ac.uk)

Received: 30 August 2017 - Discussion started: 26 September 2017

Revised: 23 December 2017 - Accepted: 7 January 2018 - Published: 13 February 2018

\begin{abstract}
Cloud droplet number concentration (CDNC) is the key state variable that moderates the relationship between aerosol and the radiative forcing arising from aerosolcloud interactions. Uncertainty related to the effect of anthropogenic aerosol on cloud properties represents the largest uncertainty in total anthropogenic radiative forcing. Here we show that regionally averaged time series of the ModerateResolution Imaging Spectroradiometer (MODIS) observed CDNC of low, liquid-topped clouds is well predicted by the MERRA2 reanalysis near-surface sulfate mass concentration over decadal timescales. A multiple linear regression between MERRA2 reanalyses masses of sulfate $\left(\mathrm{SO}_{4}\right)$, black carbon (BC), organic carbon (OC), sea salt (SS), and dust (DU) shows that CDNC across many different regimes can be reproduced by a simple power-law fit to near-surface $\mathrm{SO}_{4}$, with smaller contributions from BC, OC, SS, and DU. This confirms previous work using a less sophisticated retrieval of CDNC on monthly timescales. The analysis is supported by an examination of remotely sensed sulfur dioxide $\left(\mathrm{SO}_{2}\right)$ over maritime volcanoes and the east coasts of North America and Asia, revealing that maritime CDNC responds to changes in $\mathrm{SO}_{2}$ as observed by the ozone monitoring instrument (OMI). This investigation of aerosol reanalysis and top-down remote-sensing observations reveals that emission controls in Asia and North America have decreased CDNC in their maritime outflow on a decadal timescale.
\end{abstract}

\section{Introduction}

The degree to which anthropogenic aerosol has affected the Earth's albedo by altering cloud properties remains the largest uncertainty in our understanding of how much humans have changed the top-of-atmosphere energy balance and by extension what the observed trend in surface temperature tells us about the climate's sensitivity to perturbation (Forster, 2016; Boucher et al., 2014; Andreae et al., 2005). Aerosol indirect effects can be grouped into two categories: the first indirect effect, or Twomey effect (Twomey, 1977), by which enhanced concentrations of cloud condensation nuclei $(\mathrm{CCN})$ enhance CDNC (for a fixed liquid water content), leading to an increase in cloud albedo; and the lifetime, or Albrecht effect (Albrecht, 1989), by which enhanced CDNC suppresses precipitation and leads to thicker or more persistent clouds and higher cloud albedo. The first indirect effect has been supported by numerous empirical studies relating remotely sensed aerosol properties to remotely sensed CDNC (Bellouin et al., 2013; Gryspeerdt et al., 2016; Patel et al., 2017; Quaas et al., 2008, 2009; Matsui et al., 2006; Nakajima et al., 2001; Sekiguchi et al., 2003), although whether aerosol affects cloud lifetime is still debated (McCoy et al., 2017b; Malavelle et al., 2017; Gryspeerdt et al., 2016; Mace and Avey, 2016). Studies have utilized the natural laboratory provided by transient degassing volcanoes to study cloud responses to changes in aerosol (Mace and Abernathy, 2016; Gassó, 2008; Yuan et al., 2011; Malavelle et al., 2017; Mc- 
Coy and Hartmann, 2015). In this vein, McCoy et al. (2017a) used aerosol reanalysis to provide additional information regarding aerosol speciation and vertical structure. They found that monthly mean CDNC and sulfate mass concentration near the surface were linked by a power-law relationship that remained robust across different regions with very different aerosol properties and cloud regimes, but their analysis was hampered by remote-sensing bias leading to different regions having a different constant term in the log-log fit between CDNC and sulfate $\left(\mathrm{SO}_{4}\right)$. This study utilizes a new CDNC dataset filtered for retrieval error that rectifies these biases. We show that the power-law relationship between sulfate and CDNC applies across all regimes. Further, we show that long-term trends in observed sulfur dioxide $\left(\mathrm{SO}_{2}\right)$ and reanalysis $\mathrm{SO}_{4}$ predict trends in $\mathrm{CDNC}$, indicating that changes in sulfur have the ability to influence CDNC on an interannual timescale that is of relevance to the aerosolcloud radiative forcing.

\section{Methods}

The analysis performed in this study parallels the analysis in McCoy et al. (2017a). Here a much more refined dataset is used to analyze the period 2003-2015 (as opposed to 20012013 in McCoy et al., 2017a) expanded to a daily timescale over the entire globe (21379 174 daily $1^{\circ} \times 1^{\circ}$ observations). Aerosol reanalysis from MERRA2 is used to gain insight into speciation and vertical distribution that is not provided by remote-sensing analyses that use column-integrated $\mathrm{CCN}$ proxies such as aerosol index (AI) or aerosol optical depth (AOD). It has been demonstrated that model-simulated AI accurately predicts changes in CDNC in contrast to AOD (Gryspeerdt et al., 2017), but observations of AI are still subject to near-cloud retrieval artifacts (Christensen et al., 2017). The aerosol species considered in the present analysis are dust (DU), sea salt (SS), black carbon (BC), organic carbon (OC), and sulfate $\left(\mathrm{SO}_{4}\right)$. As in McCoy et al. (2017a), DU and SS masses as predicted by MERRA2 are restricted to submicron sizes because these will be more numerous as CCN (Ghan et al., 1998). Similarly, only hydrophilic BC and $\mathrm{OC}$ as predicted by MERRA 2 are considered. The daily mean near-surface $(\sim 1 \mathrm{~km}$ altitude) mass concentrations of all aerosol species are calculated by averaging the 3-hourly aerosol mass concentration at the $910 \mathrm{hPa}$ model level in MERRA2 resolved at $0.5^{\circ} \times 0.626^{\circ}$ resolution to $1^{\circ} \times 1^{\circ}$ and daily resolution.

In this paper and in McCoy et al. (2017a) CDNC is calculated from MODIS effective radius $\left(r_{\mathrm{e}}\right)$ and optical depth $(\tau)$ retrievals using the adiabatic cloud assumption following Grosvenor and Wood (2014). MODIS simultaneously retrieves $\tau$ and $r_{\mathrm{e}}$ via a bispectral algorithm that uses reflectances from both a nonabsorbing visible wavelength $(0.65 \mu \mathrm{m}$ over land and $0.86 \mu \mathrm{m}$ over the ocean) and an absorbing shortwave infrared wavelength $(1.6,2.1$, or $3.7 \mu \mathrm{m}$;
Nakajima and King, 1990). In McCoy et al. (2017a) $1^{\circ} \times 1^{\circ}$ daily mean MODIS $r_{\mathrm{e}}$ and $\tau$ values were used to calculate CDNC values, which were then averaged to monthly resolution. The use of this CDNC dataset may be problematic in some regions for a number of reasons (see also McCoy et al., 2017a): (1) it is subject to high solar zenith angle biases in the individual swaths, which were averaged together to create each daily data point; (2) biases may be present due to the use of area-averaged $r_{\mathrm{e}}$ and $\tau$ rather than using pixellevel values for the CDNC calculation; (3) the dataset was not filtered to include low-altitude clouds only, which may have led to a lack of connectivity between surface aerosol sources and cloud CDNC; (4) the CDNC was calculated using the $2.1 \mu \mathrm{m}$ MODIS channel $r_{\mathrm{e}}$, which is likely to be affected more strongly by cloud heterogeneity biases than the $3.7 \mu \mathrm{m}$ channel (Zhang et al., 2012).

In the present study, level-2 swath data (joint product) from MODIS collection 5.1 (King et al., 2003) are filtered to remove problematic retrievals at a pixel level following Grosvenor and Wood (2014), including the removal of pixels with a solar zenith angle greater than $65^{\circ}$. The daily mean $\mathrm{CDNC}$ at $1^{\circ} \times 1^{\circ}$ resolution is calculated using filtered level2 swath data and only low (cloud tops below $3.2 \mathrm{~km}$ ), liquid clouds were used to calculate CDNC. Only $1^{\circ} \times 1^{\circ}$ regions where the cloud fraction exceeds $80 \%$ are considered valid (Bennartz et al., 2011) and the CDNC is calculated using the $3.7 \mu \mathrm{m}$ MODIS channel $r_{\mathrm{e}}$. In the remainder of this paper MERRA2 data are only considered for days and $1^{\circ} \times 1^{\circ}$ regions when and where MODIS is able to perform a retrieval of CDNC within this set of criteria, notably in the comparison between predicted and observed CDNC in Sect. 3.2 and in the comparison of long-term trends in Sect. 3.3. The mean CDNC over the period 2003-2015 is shown in Fig. 1. It should be noted that Fig. 1 is intended to illustrate the mean CDNC over the existing dataset and CDNC values are not weighted to equally represent the seasonal cycle; for example, in midlatitude winter, retrievals of CDNC are not possible and these areas would be blank in a climatologically weighted map. Values of CDNC are retrieved only when a cloud is present and are thus in-cloud values and are not the average of cloud-free and cloudy regions.

The CDNC retrieval from MODIS and the aerosol reanalysis are independent datasets. The AOD observed by MODIS (in addition to other instruments) is used to constrain aerosol loading in the MERRA2 reanalysis, in which AOD is corrected for near-cloud aerosol swelling (Rienecker et al., 2011; Randles et al., 2016; Buchard et al., 2015). However, to develop the usefulness of MODIS CDNC as a measure of aerosol-cloud interactions and the microphysical state of liquid-topped clouds, we utilize in situ aircraft measurements of $\mathrm{CDNC}$ and the sulfur dioxide $\left(\mathrm{SO}_{2}\right)$ retrieved by the ozone monitoring instrument (OMI). The dataset used in this study to examine changes in $\mathrm{SO}_{2}$ is the planetary boundary layer (PBL) $\mathrm{SO}_{2}$ calculated using principal component analysis to reduce artifacts and noise ( $\mathrm{Li}$ et al., 2013). The retrieval re- 


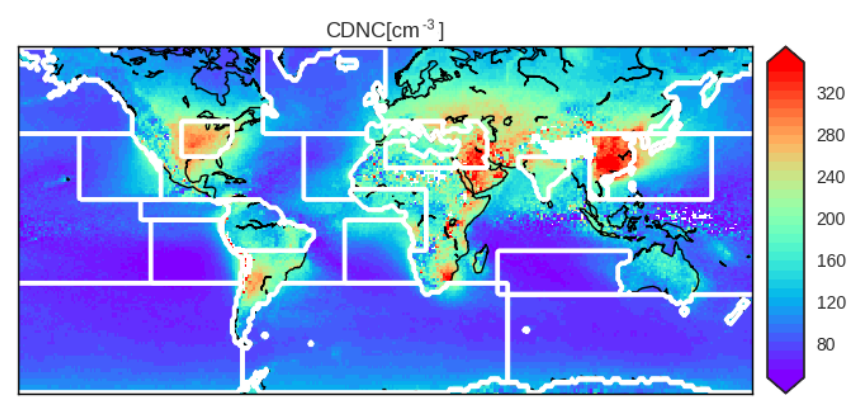

Figure 1. The mean CDNC from 2003-2015 observed by MODIS. Boxes over land and ocean used to examine different regimes in Fig. 3 are shown in white.

quires a clear sky, making the $\mathrm{SO}_{2}$ retrievals noncoincident with $\mathrm{CDNC}$ retrievals. However, in this study $\mathrm{SO}_{2}$ is only considered on a regional scale, as opposed to attempting to colocate it with CDNC data, so the locally noncoincident nature of these retrievals is not an issue.

We evaluated both volcanic point sources in relatively pristine maritime regions (Carn et al., 2017) and the emissions from Asia and North America (Krotkov et al., 2016). Volcanic plumes and anthropogenic emissions produce very different $\mathrm{SO}_{2}$ signatures, and large volcanic eruptions need to be removed to examine the effect of anthropogenic sources (Krotkov et al., 2016). The 2008 eruption of Kasatochi emitted a large quantity of sulfur dioxide near $10-12 \mathrm{~km}$ of altitude (Krotkov et al., 2010), rendering the data from August 2008 over the US east coast spurious in terms of examining the trend in anthropogenic sulfur emissions. This has been noted in previous studies (Krotkov et al., 2016) and all data for August 2008 have been removed from the analysis of the long-term trend in this region.

It is important to evaluate whether MODIS CDNC offers a useful measure of the real mean CDNC for which in situ observations are likely to provide an accurate proxy. We take a different tack from previous studies whose goal was to evaluate whether MODIS CDNC is reliable on a pixel-by-pixel basis (Painemal and Zuidema, 2011; Bennartz and Rausch, 2017). Bennartz and Rausch (2017) showed that their CDNC data averaged over both $\sim 0.2 \times 0.2$ and $0.5 \times 0.5^{\circ}$ regions correlated strongly with airborne observations from the VOCALS-REX campaign (Painemal and Zuidema, 2011). Here we reprise the analysis in Bretherton et al. (2010) and examine whether the average MODIS retrieval from the sampled cloud population is similar to an average aircraft observation. Aircraft measurements are taken from literature sources detailing systematic transects across regions with liquid-topped cloud (Lachlan-Cope et al., 2016; Ma et al., 2010; Hegg et al., 2007; Allen et al., 2011; Lu et al., 2007). All in situ CDNC values are reported in the text of the aforementioned references. The flight-leg mean CDNC reported by each study is compared to the relevant MODIS CDNC. Because MODIS CDNC retrievals that are considered reliable by our methodology can be quite sparse, an average of the region within $\pm 1.5^{\circ}$ of the mean location of the flight leg and 1 day before and after is taken to calculate the mean CDNC that MODIS would equivalently measure during the flight leg. This broad averaging of the CDNC population is different than the more targeted analysis presented in Bennartz and Rausch (2017). We reiterate that this analysis is only provided to show that in situ and remotely sensed CDNC are correlated. A more in-depth evaluation of remotely sensed CDNC using in situ CDNC will be left to future analysis pending the creation of a database of in situ CDNC.

Finally, in this study we subdivide our global dataset into subregions to show sensitivity to sample. These regions are similar to the regions defined in McCoy et al. (2017a) and are shown in Fig. 1. Latitude and longitude ranges are given in Table 1.

\section{Results}

In this section, we evaluate how closely aircraft and satellite measurements match each other in keeping with previous studies (Bretherton et al., 2010; Painemal and Zuidema, 2011; Bennartz and Rausch, 2017). We also examine how much daily variability in aerosol species influences CDNC and how this variability is able to predict trends and interannual variability in observed CDNC.

\subsection{Comparison of in situ and observed CDNC}

First, we establish whether our CDNC concentration dataset is consistent with in situ measurements. To evaluate the CDNC observations from our dataset we compare them to aircraft observations over a wide range of different regimes. Data from aircraft campaigns were taken from published literature values detailing mean $\mathrm{CDNC}$ for individual flight legs. The idea underlying this methodology is that if the aircraft and MODIS are both measuring the same population, then their mean CDNC values should agree, assuming that both the aircraft and MODIS are sampling randomly. Aircraft measurements from the Antarctic Peninsula, Northern China, and the Peruvian and Californian stratocumulus decks are compared to MODIS CDNC (Fig. 2). The correlation between aircraft and satellite observations is $r=0.68$. This result is very near the correlation found by Bretherton et al. (2010) using only the VOCALS-REX data, although it is worth noting that the substantial number of in-cloud transects from that study significantly contributes to the weight of the data examined here. When the data from all of the flight legs are binned together most of the bin mean CDNCs from aircraft and remote-sensing observations agree within the standard error in the estimation of the bin means $(\sigma / \sqrt{n}$; Fig. 2). It is important to note that this analysis is intended to illustrate that the $\mathrm{CDNC}$ measured by aircraft and the $\mathrm{CDNC}$ ob- 
Table 1. Details of the regions considered in this study (see also Fig. 1). For each region the coefficients relating CDNC to predictors from Eq. (1) are shown along with the correlation coefficient of the regression model in that region. The constant term in the regression is shown under $b$. The latitude-longitude bounding box of each region is shown and it is noted if data are restricted to being over land or oceans.

\begin{tabular}{|c|c|c|c|c|c|c|c|c|c|c|}
\hline & $\mathrm{SO}_{4}$ & DU & $\mathrm{BC}$ & $\mathrm{OC}$ & SS & $b$ & Land-sea & Lon & Lat & $r$ \\
\hline Peruvian & 0.3 & 0.09 & -0.06 & 0.04 & -0.15 & 1.7 & Ocean & $115-65^{\circ} \mathrm{W}$ & $30^{\circ} \mathrm{S}-0^{\circ} \mathrm{N}$ & 0.64 \\
\hline Namibian & 0.21 & 0.14 & 0.38 & -0.32 & -0.12 & 2.27 & Ocean & $20^{\circ} \mathrm{W}-20^{\circ} \mathrm{E}$ & $30^{\circ} \mathrm{S}-0^{\circ} \mathrm{N}$ & 0.61 \\
\hline Australian & 0.44 & 0.09 & 0.01 & -0.03 & -0.12 & 1.94 & Ocean & $55-120^{\circ} \mathrm{E}$ & $35-15^{\circ} \mathrm{S}$ & 0.57 \\
\hline Californian & 0.2 & 0 & -0.03 & 0.13 & -0.04 & 2.03 & Ocean & $150-110^{\circ} \mathrm{W}$ & $10-40^{\circ} \mathrm{N}$ & 0.43 \\
\hline Canarian & 0.29 & 0.07 & -0.08 & 0.11 & -0.06 & 1.95 & Ocean & $40-5^{\circ} \mathrm{W}$ & $10-40^{\circ} \mathrm{N}$ & 0.53 \\
\hline China & 0.27 & 0.01 & 0.01 & 0.05 & -0.02 & 2.11 & Ocean & $100-160^{\circ} \mathrm{E}$ & $10-40^{\circ} \mathrm{N}$ & 0.63 \\
\hline North Atlantic & 0.24 & -0.03 & 0.15 & -0.03 & -0.07 & 2.03 & Ocean & $60^{\circ} \mathrm{W}-0^{\circ} \mathrm{E}$ & $40-70^{\circ} \mathrm{N}$ & 0.45 \\
\hline Northeast Pacific & 0.08 & -0.04 & 0.07 & 0.03 & -0.02 & 1.96 & Ocean & $180-120^{\circ} \mathrm{W}$ & $40-70^{\circ} \mathrm{N}$ & 0.24 \\
\hline Northwest Pacific & 0.11 & -0.05 & 0.18 & -0.04 & -0.01 & 2.17 & Ocean & $120-180^{\circ} \mathrm{E}$ & $40-70^{\circ} \mathrm{N}$ & 0.35 \\
\hline Southeast Pacific & 0.29 & 0.09 & -0.14 & 0.02 & -0.1 & 1.64 & Ocean & $180-70^{\circ} \mathrm{W}$ & $70-30^{\circ} \mathrm{S}$ & 0.45 \\
\hline South Atlantic & 0.29 & 0.03 & -0.09 & 0.04 & -0.11 & 1.73 & Ocean & $70^{\circ} \mathrm{W}-60^{\circ} \mathrm{E}$ & $70-30^{\circ} \mathrm{S}$ & 0.38 \\
\hline South Indian Ocean & 0.3 & -0.02 & -0.04 & 0.01 & -0.07 & 1.81 & Ocean & $60-180^{\circ} \mathrm{E}$ & $70-35^{\circ} \mathrm{S}$ & 0.37 \\
\hline Galapagos & 0.09 & 0.06 & 0.1 & -0.04 & 0 & 2.25 & Ocean & $120-70^{\circ} \mathrm{W}$ & $0-10^{\circ} \mathrm{N}$ & 0.37 \\
\hline Chinese stratus & 0.27 & 0.03 & -0.16 & 0.11 & -0.02 & 2.05 & Land & $100-130^{\circ} \mathrm{E}$ & $10-40^{\circ} \mathrm{N}$ & 0.42 \\
\hline Amazon & 0.22 & 0 & 0.06 & -0.03 & 0.01 & 2.37 & Land & $80-30^{\circ} \mathrm{W}$ & $15^{\circ} \mathrm{S}-10^{\circ} \mathrm{N}$ & 0.46 \\
\hline Equatorial Africa & 0.06 & -0.02 & 0.01 & 0.07 & 0.07 & 2.41 & Land & $20^{\circ} \mathrm{W}-20^{\circ} \mathrm{E}$ & $15^{\circ} \mathrm{S}-15^{\circ} \mathrm{N}$ & 0.37 \\
\hline North America & 0.18 & 0.02 & 0.2 & -0.13 & 0.02 & 2.55 & Land & $100-75^{\circ} \mathrm{W}$ & $30-45^{\circ} \mathrm{N}$ & 0.33 \\
\hline India & -0.02 & -0.01 & 0.39 & -0.24 & 0.05 & 2.71 & Land & $65-90^{\circ} \mathrm{E}$ & $10-30^{\circ} \mathrm{N}$ & 0.41 \\
\hline Europe & 0.18 & 0.02 & 0.08 & 0 & 0.02 & 2.42 & Land & $0-50^{\circ} \mathrm{E}$ & $25-45^{\circ} \mathrm{N}$ & 0.37 \\
\hline
\end{tabular}

served by MODIS are not drawn from entirely different populations and that the correlation between flight-leg CDNC and remotely sensed CDNC is similar to previous analyses (Bretherton et al., 2010). A more rigorous analysis of aircraft and the MODIS CDNC dataset shown in this paper will be undertaken in a future work pending the compilation of a dataset of aircraft CDNC in the spirit of the Global Aerosol Synthesis and Science Project (GASSP; Reddington et al., 2017).

\subsection{Covariability between observations of daily CDNC and MERRA2 aerosol mass}

We have shown that the daily mean CDNC that MODIS observes is consistent on average with in situ observations. How then does this satellite retrieval covary with aerosol mass concentrations on a global scale? We split our global dataset into many different regions selected to focus on either particular cloud regimes or different aerosol emission sources (see discussion in McCoy et al., 2017a). If the dependence of CDNC on aerosol is similar across these regions, then it supports the idea that this relationship is mechanistic.

We find that, as in previous studies, CDNC is strongly dependent on sulfate mass (Fig. 3a) and this dependence is similar across many of the regions shown in Fig. 1. Notable exceptions are the North Pacific midlatitudes and the Indian subcontinent. The former may relate to the challenge for reanalysis of predicting daily $1^{\circ} \times 1^{\circ}$ sulfate mass concentration after advection from Asia across the Pacific; the Indian subcontinent may represent a region where substan- tial emissions of carbonaceous species render variability in sulfate less important, or it may relate to retrieval difficulties in distinguishing cloud from haze over the subcontinent (Ramanathan et al., 2001). We fit the following regression model:

$$
\begin{aligned}
\log _{10} \mathrm{CDNC} & =a_{1} \log _{10}\left(\mathrm{SO}_{4}\right)+a_{2} \log _{10}(\mathrm{BC}) \\
& +a_{3} \log _{10}(\mathrm{OC})+a_{4} \log _{10}(\mathrm{SS}) \\
& +a_{5} \log _{10}(\mathrm{DU})+b
\end{aligned}
$$

which differs from the previous study (McCoy et al., 2017a) by adding organic carbon as a predictor. Several of the predictors covary strongly (Fig. S1 in the Supplement). We attempt to ameliorate the issue of collinearity by training separate regression models in each of the regions shown in Fig. 1. For example, the correlation between $\mathrm{BC}$ and $\mathrm{SO}_{4}$ will be high in regions with significant biomass burning, but nonexistent in the remote Southern Ocean. If the regression coefficient relating CDNC to $\mathrm{SO}_{4}$ remains consistent between these regions, then it is a good indication that this relationship is robust.

The coefficients from the multiple linear regression model trained in each of the areas shown in Fig. 1 are shown in Fig. 3b. Because some aerosol species have little to no variability, the value of each coefficient is shown scaled by the standard deviation over all observations from 2003-2015 of the relevant term in the regression model. Correlations and unscaled regression model coefficients for each region are given in Table 1. If we only train the regression model using daily mean data from stratocumulus decks, then the co- 


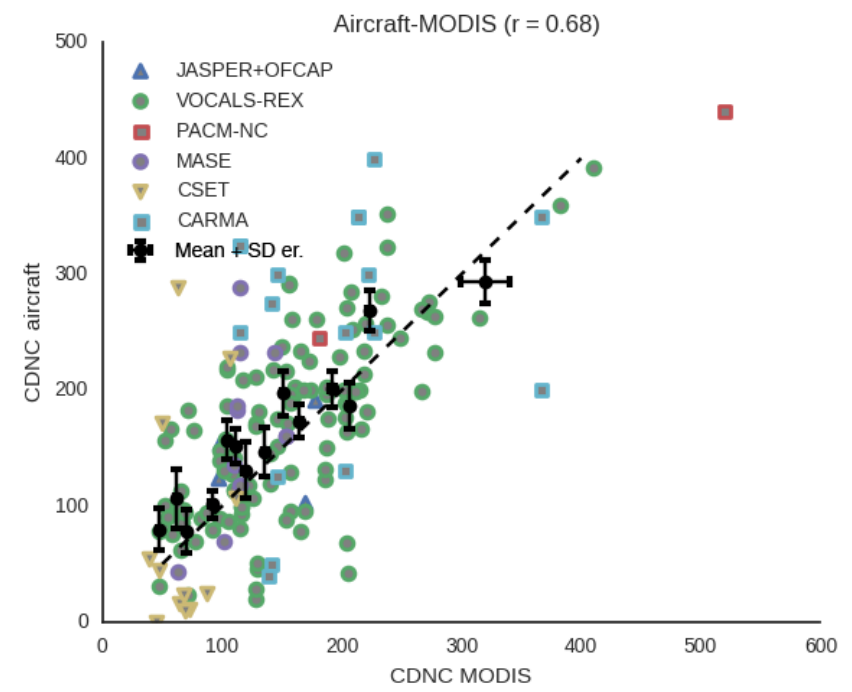

Figure 2. Aircraft-measured CDNC versus MODIS CDNC where MODIS CDNC has been averaged within $1.5^{\circ}$ of the flight leg and 1.5 days. Data from JASPER and OFCAP near the Antarctic Peninsula (Lachlan-Cope et al., 2016); VOCALS-REX off the coast of Peru (Allen et al., 2011); MASE, CSET, and CARMA off the California coast (Lu et al., 2007; Hegg et al., 2007); PACM-NC refers to data from Northern China near Beijing and Tianjin (Ma et al., 2010). The one-to-one relation is shown as a dashed line, the mean of the data is shown with black dots taken over equal quantiles of the data, and the standard error in the mean is shown with error bars.

efficient relating $\log _{10}$ sulfate to $\log _{10} \mathrm{CDNC}$ remains approximately unchanged relative to McCoy et al. (2017a; Fig. 3b, and Table 1), supporting the estimate by McCoy et al. (2017a) that the increase in CDNC caused by sulfate results in a radiative forcing of $-0.97 \mathrm{Wm}^{-2}$. Overall, it appears that daily aerosol reanalysis has the ability to predict day-to-day variations in observed CDNC with a remarkably high degree of skill. It is also interesting to note that the sulfate-CDNC relation shown here seems quite similar between regions with very strong seasonal cycles in emissions (such as the Southern Ocean; McCoy et al., 2015) and regions where emissions are primarily anthropogenic and not strongly affected by the seasonal cycle (such as East Asia; McCoy et al., 2017a; Bennartz et al., 2011) as well as across many different meteorological regimes. Based on this it seems that seasonal variability in emissions and atmospheric processes do not strongly affect this relationship.

One surprising result from this analysis is the weakly negative to near-zero dependence of CDNC on submicron sea salt mass. Sea salt is plentiful and hygroscopic and it would seem reasonable to suspect that it would significantly affect CDNC. Analysis of the dependence of CDNC on sea salt and sulfate shows that sea salt mass is only important for very low sea salt mass (Fig. 4; for values of $\log _{10}$ SS less than roughly -3 , increasing sea salt increases CDNC). Presumably this indicates that in situations in which sea salt emissions are (a)

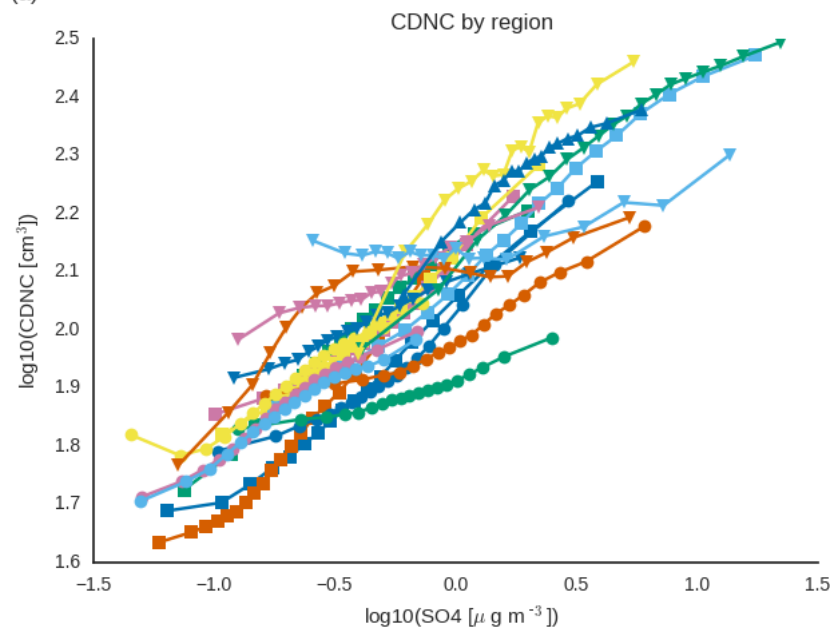

Region

$$
\begin{aligned}
& \rightarrow \text { Peruvian } \quad \rightarrow \text { Northeast Pacific } \rightarrow \text { Chinese stratus } \\
& \rightarrow \text { - Namibian } \rightarrow \text { Northwest Pacific } \longrightarrow \text { Amazon } \\
& \because \text { Australian } \quad \longrightarrow \text { Southeast Pacific } \quad \longrightarrow \text { Equatorial Africa } \\
& \because \text { Californian } \quad \longrightarrow \text { South Atlantic } \quad-\text { North America } \\
& - \text { Canarian } \quad \longrightarrow \text { South Indian Ocean } \quad \div \text { India } \\
& \rightarrow \text { China } \rightarrow \text { Galapagos } \rightarrow \text { Europe } \\
& \rightarrow \text { North Atlantic }
\end{aligned}
$$

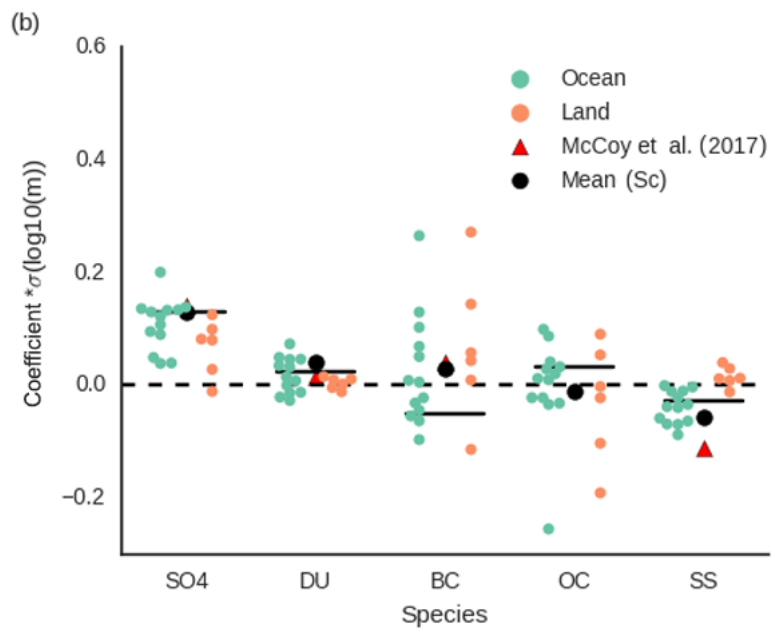

Figure 3. (a) Daily CDNC from MODIS binned by boundary layer sulfate mass from MERRA2. Regions (Fig. 1) are noted in the legend. (b) The multiple linear regression coefficients relating CDNC to boundary layer aerosol mass concentrations. Each coefficient is scaled by the standard deviation of the relevant predictor in the regression model. Black lines show the coefficient values if all available data are used to train the regression model, triangles show equivalent values from McCoy et al. (2017a) derived from measurements over stratocumulus decks, and black circles show the mean coefficient values from the present study restricted to stratocumulus decks. Note that BC and OC are the masses predicted by MERRA2 to be hydrophilic, and sea salt (SS) and dust (DU) are the masses predicted to be submicron. These distinctions have been made to try and look at the most CCN-relevant aerosol mass in these species. Coefficients for each region are shown in Table 1. 


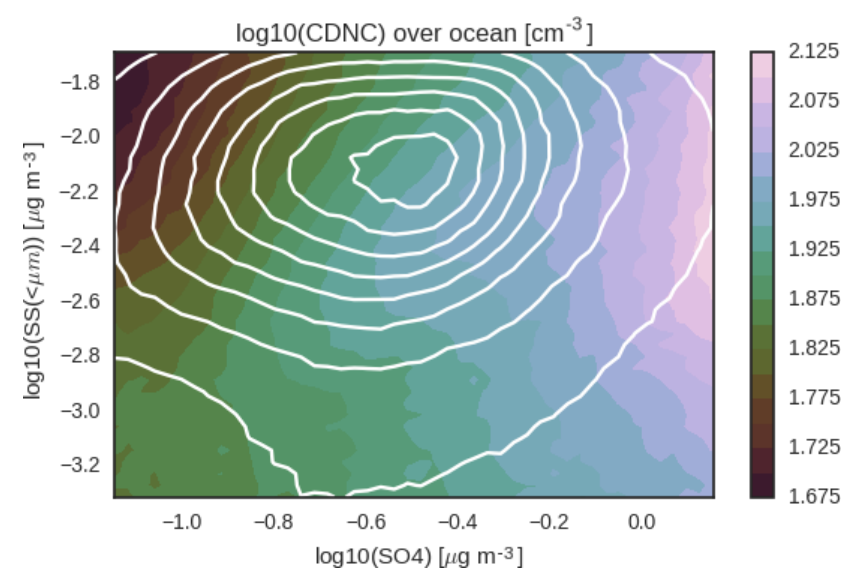

Figure 4. The dependence of CDNC on submicron sea salt and sulfate mass predicted by MERRA2. All variables are shown in $\log _{10}$ space. White lines show the probability distribution of sea salt and sulfate in the observations. Equivalent plots replacing sea salt with dust, black carbon, and organic carbon are shown in Fig. S2.

low it has a limiting effect on the creation of CCN. However, the effect of sea salt emissions on CDNC appears to be saturated for the majority of observations with increasing sea salt slightly decreasing CDNC (Fig. 4; the distribution of MERRA2 sea salt mass over oceans is shown as white contours). This is why the linear regression model assigns it a weakly negative coefficient (Fig. 3b). This reduction in CDNC for increasing SS mass may be consistent with large sea salt particles reducing the supersaturation, resulting in less accumulation-mode aerosol being activated (Ghan et al., 1998). It is also possible that the submicron sea salt aerosol number does not scale with mass. We have constrained the sea salt mass concentration to only include submicron sea spray in an attempt to consider only the most CCN-relevant aerosol. However, the MERRA2 reanalysis simply uses wind speed and SST to predict sea spray flux based on a parameterization (Gong, 2003; Jaeglé et al., 2011) and in the context of the analysis presented in this paper the relation between submicron sea salt mass and CDNC is at some level the relation between near-surface wind speed and CDNC. The precise values of the coefficient should change if a different size distribution is used in the parameterization, but it is likely that the qualitative dependence of CDNC on sea salt would remain the same.

Another interesting note is the negative dependence of $\mathrm{CDNC}$ on $\mathrm{BC}$. This appears to only be a feature of low BC and OC load (Fig. S2), but this may also reflect existing issues in the MERRA2 reanalysis of carbonaceous species in terms of the representation of aerosol index and vertical distribution in relation to organic carbon (Randles et al., 2016). It is worth pointing out, however, that there are a priori physical reasons to expect black carbon to thin cloud cover via the semi-direct effect (Hansen et al., 1997). As we have seen CDNC covaries substantially with aerosol on a daily scale over the period 2003-2015 and across many different regimes. In particular, we find that sulfate aerosol covaries strongly with $\mathrm{CDNC}$, which is consistent with pioneering work examining cloud-aerosol interactions (Charlson et al., 1992). Our study provides the first systematic top-down estimate of this covariability.

\subsection{Decadal trends in CDNC driven by sulfur fluxes}

While our results are consistent with previous work regarding aerosol-cloud indirect effects, it is important to demonstrate that the sulfate-CDNC correlation is not spuriously created by, for example, advection of pollution sources being correlated with meteorological conditions that lead to high CDNC. It is also important to show predictive capability over the timescales of years and decades that are useful for understanding the radiative forcing from the aerosol-cloud interactions during the industrial era. One way to demonstrate this is by examining known sources of sulfate whose emission flux is unrelated to seasonal or meteorological variability (in contrast to biogenic sulfate, for example).

For the analysis presented in this paper we adopt the technique used in previous studies (Gassó, 2008; Mace and Abernathy, 2016; Yuan et al., 2011; McCoy and Hartmann, 2015; Malavelle et al., 2017) and examine the response of cloud properties to volcanic sulfate sources. We support this analysis by examining the systematic change in anthropogenic sulfur emissions from Asia and North America due to emissions controls (Krotkov et al., 2016) as in previous studies (Bennartz et al., 2011), although our data record extends over a period of enhanced emissions controls in East Asia and thus we anticipate a decrease in CDNC in contrast to Bennartz et al. (2011). We examine systematic changes in CDNC in maritime regions where there is outflow from anthropogenic pollution sources because McCoy et al. (2017a) inferred a strong aerosol-cloud radiative forcing in such regions based on a power-law relationship between sulfate and CDNC. Such a long-range relationship between sulfur sources and CDNC would be supportive of sulfate driving CDNC variability.

In the analysis presented below we will examine longterm trends in CDNC as observed by MODIS and predicted by MERRA2 sulfate mass. The notion that these long-term trends originate from changes in sulfur flux from volcanism or emissions controls will be supported by analysis of the boundary layer $\mathrm{SO}_{2}$ detected by the OMI instrument, which is an independent dataset to either reanalyze sulfate mass or MODIS CDNC. Days for which data over each region are missing from the time series (for example, August 2008 over North America from OMI; Krotkov et al., 2010) are filled by linear interpolation before applying a 365-day moving average. To allow ease of comparison to trends in $\log _{10}$ sulfate mass, $\log _{10}$ CDNC is shown in Fig. 5. To our knowledge this is the first study to show that variations in anthropogenic emissions drive changes in $\mathrm{CDNC}$ using remotely sensed $\mathrm{SO}_{2}$ and $\mathrm{CDNC}$. 

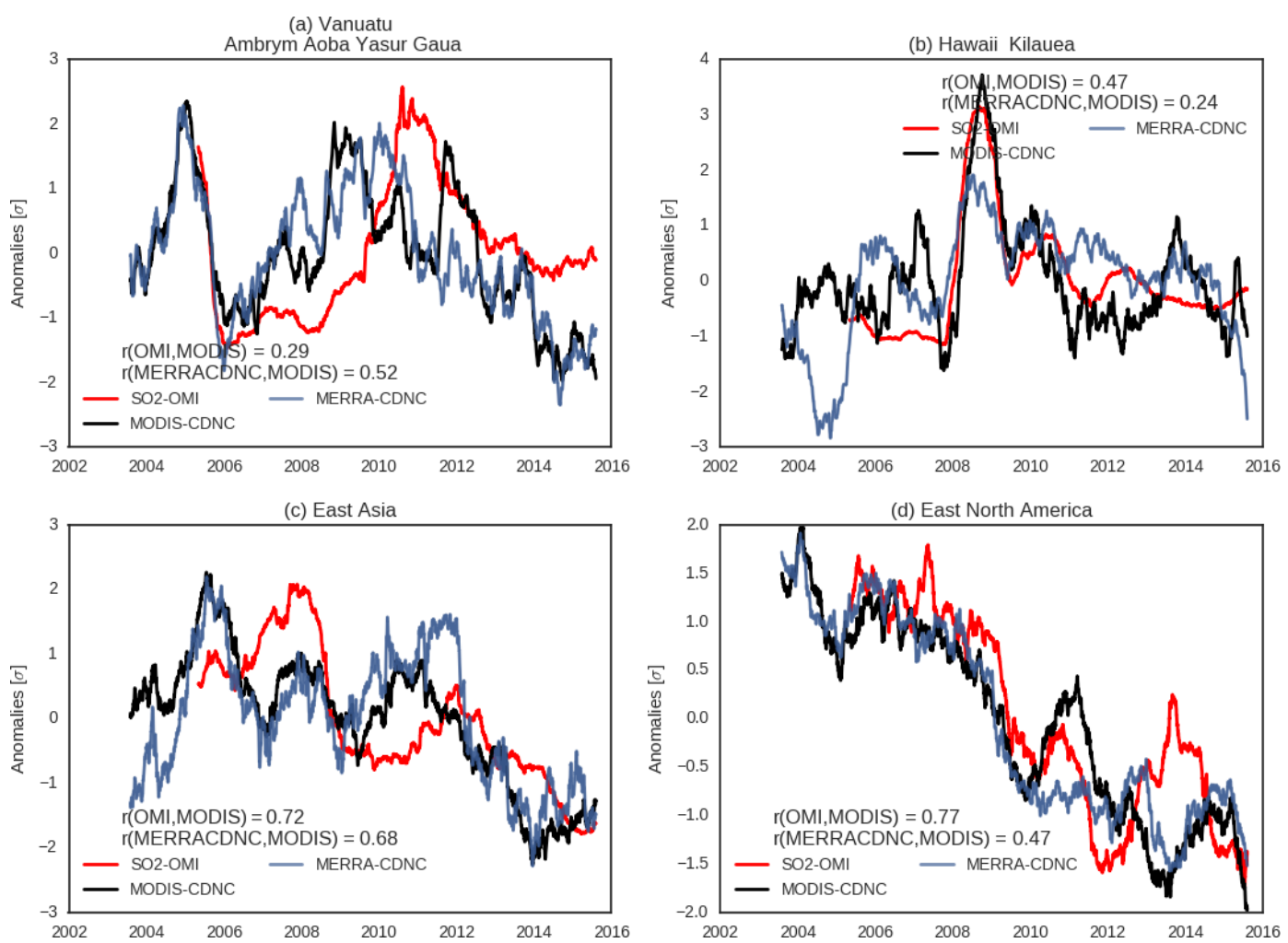

Figure 5. Sulfur dioxide $\left(\mathrm{SO}_{2}\right)$ from OMI, $\log _{10} \mathrm{CDNC}$ from MODIS, and $\log _{10} \mathrm{CDNC}$ predicted by MERRA2 $\mathrm{SO}_{4}$ over Vanuatu and Hawaii (a, b) and China and the east coast of the US (c, d). A 365-day running mean is used to smooth both time series. In (a) and (b) CDNC and $\mathrm{SO}_{2}$ are averaged within $5^{\circ}$ of the volcano. In (c) and (d) $\mathrm{SO}_{2}$ is averaged over land and CDNC is averaged off the coast. All data are plotted in standard deviations relative to the mean of the time series. The correlation between time series of CDNC from $\mathrm{MODIS}$ and SO 2 from OMI, and between predicted and observed CDNC, are noted in the legend for each figure. Note that these correlations are taken before taking the 365-day running mean. The correlation between the time series of predicted and observed CDNC after taking the running mean is noted in Fig. 6.

The volcanoes on the Pacific islands of Vanuatu and Hawaii constitute the largest volcanic sources of sulfur dioxide in the data record afforded by OMI (Carn et al., 2017). Their relatively pristine remote locations and large interannual variability in sulfur emissions make them ideal for examining covariation between $\mathrm{CDNC}$ and $\mathrm{PBL} \mathrm{SO}_{2}$. The average $\mathrm{CDNC}$ and $\mathrm{SO}_{2}$ within $5^{\circ}$ of the volcanoes are shown during the period 2003-2015 (Fig. 5a, b).

The variances in daily $\mathrm{PBL} \mathrm{SO}_{2}$ detected by $\mathrm{OMI}$ and in CDNC detected by MODIS are correlated in the vicinity of both Vanuatu and Hawaii (Fig. 5a, b). Increased volcanic activity observed in situ at Kilauea in Hawaii during 20082010 (Elias and Sutton, 2007; Longo et al., 2010) translates to a strong increase in $\mathrm{SO}_{2}$ as measured by $\mathrm{OMI}$ and in CDNC as measured by MODIS, with a nearly 4 standard deviation increase in $\mathrm{CDNC}$ and $\mathrm{SO}_{2}$ at its peak. The activity near Vanuatu is less pronounced, but the MODISobserved CDNC still covaries with long-term trends in OMI $\mathrm{SO}_{2}$. These results suggest that variability in CDNC on the timescales of months and years is being driven by volcanism in these regions.
Volcanic sources play an important role in determining preindustrial CDNC (Schmidt et al., 2012), but one of the central goals of the analysis presented in this work is to offer a constraint on CDNC changes due to anthropogenic activity. Emissions controls in both China and the United States have resulted in steadily decreased $\mathrm{SO}_{2}$ emissions in these regions over the observational record from OMI (Krotkov et al., 2016). The $\mathrm{SO}_{2}$ measured over land on the east coast of North America $\left(30-45^{\circ} \mathrm{N}, 85-65^{\circ} \mathrm{W}\right)$ and Asia $\left(10-40^{\circ} \mathrm{N}\right.$, $110-120^{\circ} \mathrm{E}$ ) is shown in Fig. $5 \mathrm{c}$, d. This decrease in $\mathrm{SO}_{2}$ over continents correlates well with CDNC observed over the Pacific $\left(10-40^{\circ} \mathrm{N}, 110-150^{\circ} \mathrm{E}\right)$ and Atlantic $\left(30-45^{\circ} \mathrm{N}, 80\right.$ $65^{\circ} \mathrm{W}$; Fig. 5c, d). Land domains were chosen to match the regions of $\mathrm{SO}_{2}$ production in China and the US examined in Krotkov et al. (2016). As noted in Krotkov et al. (2016), the Yangtze River delta, Pearl River delta, and Sichuan Basin contribute the majority of emissions in China, while Pennsylvania and the Ohio River valley contribute strongly to North American emissions. The averages over land have been selected to capture these regions and agree with previous studies (Krotkov et al., 2016). The accompanying maritime out- 
flow regions have been chosen to match the same latitude range and capture the region of enhanced CDNC shown in Fig. 1 .

It is interesting to note that the trends in $\mathrm{SO}_{2}$ over Asia and North America and related CDNC changes over the Pacific and Atlantic parallel the history of emissions controls in China and the United States (US), supporting the idea that the observed trend is related to aerosol affecting cloud properties as opposed to some systematic change in circulation during the observational record. In the US, various federaland state-level controls on sulfur emissions, such as the 1990 Clean Air Act, the 2010 Acid Rain Program, and the 2009 Clean Air Interstate Rule, have led to a steady decrease in $\mathrm{SO}_{2}$ over the US east coast. This trend appears in OMI observations and is corroborated by ground-based and aircraft inventories (Krotkov et al., 2016; He et al., 2016; Hand et al., 2012).

Sulfur dioxide over China does not exhibit as monotonic a behavior as the east coast of North America. $\mathrm{SO}_{2}$ decreases substantially during the period 2008-2010, which has been suggested to result from a combination of economic recession and the emission control measures put in place before the 2008 Olympic Games in Beijing (Krotkov et al., 2016; Li et al., 2010; Lu et al., 2011; Mijling et al., 2009; Witte et al., 2009). CDNC over the Pacific decreases during this period as well, although not for as long as $\mathrm{SO}_{2}$ (Fig. 5c). Since 2012, $\mathrm{SO}_{2}$ over eastern China has decreased substantially. This may reflect emission controls implemented as part of the 12th 5-year plan (Tian et al., 2013; Zhao et al., 2013) and cleaner coal-fired technology (Wang et al., 2015). The strong decrease in $\mathrm{SO}_{2}$ from 2012 is mirrored in trends in CDNC over the Pacific. Taken together, these long-term trends in maritime CDNC responding to continental emissions of sulfur dioxide underline the link between sulfate and CDNC.

In addition to the strong pollution sources on the North American east coast and East Asia, we also investigated interannual variability associated with the European Union and the stratocumulus decks listed in Table 1. Interannual variability in these regions is less dramatic and $\mathrm{SO}_{2}$ is generally below the OMI detection threshold (Krotkov et al., 2016), making interpretation of the long-term trends in $\mathrm{SO}_{2}$ difficult. However, in the European Union and Peruvian stratocumulus regions, variabilities in $\mathrm{CDNC}$ and $\mathrm{SO}_{2}$ agree moderately well (Figs. S3 and S4). Overall, given the difficulties in retrieving boundary layer $\mathrm{SO}_{2}$ (as discussed in the Methods section) and the large regions being averaged, the correlations between time series of $\mathrm{SO}_{2}$ and $\mathrm{CDNC}$ are quite high across regions.

We have examined the covariability between remotely sensed $\mathrm{PBL} \mathrm{SO}_{2}$ and $\mathrm{CDNC}$. In both pristine and polluted regions, long-term trends in CDNC appear to be driven by changes in sulfur flux (Fig. 5). This leaves us with an important question for this analysis: how well does the sulfate mass from MERRA2 replicate these decadal trends? The longterm trends in $\log _{10}$ CDNC are well correlated with long-

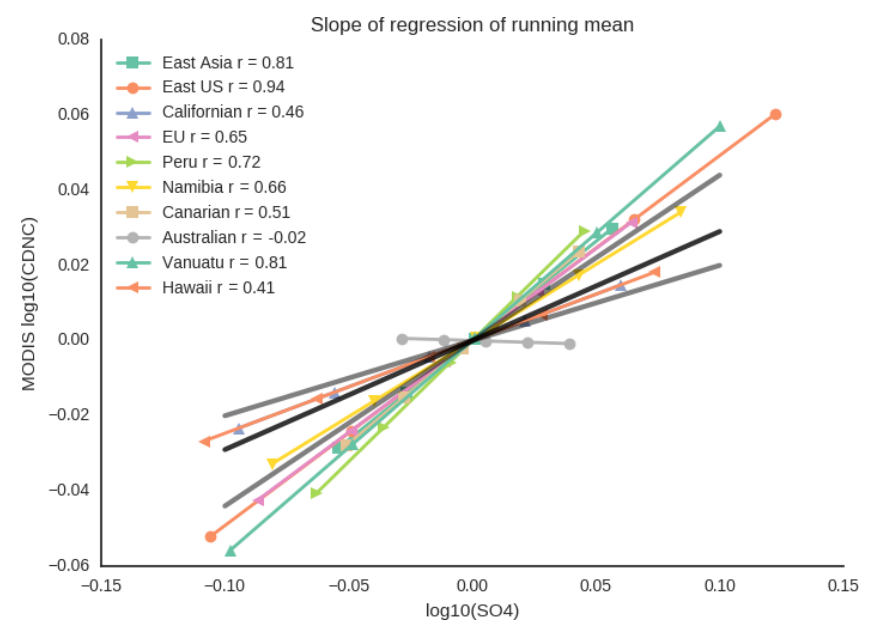

Figure 6. An illustration of the slope of the linear regression of regionally and temporally averaged $\log _{10} \mathrm{SO}_{4}$ on $\log _{10}$ CDNC. Both $\mathrm{CDNC}$ and $\mathrm{SO}_{4}$ are averaged in each region and smoothed with a 365-day moving average (see Fig. 5). Each region is noted in the legend along with the correlation between $\log _{10}$ CDNC and $\log _{10}$ $\mathrm{SO}_{4}$. The $\times$ range of the lines corresponds to the range of regionally and temporally averaged $\log _{10} \mathrm{SO}_{4}$ in each region. Slopes derived from $1^{\circ} \times 1^{\circ}$ daily data in the stratocumulus regions are shown using black and gray solid lines. The mean coefficient from the stratocumulus regions (Table 1) is shown as a black line. The minimum and maximum coefficients from the stratocumulus regions (California and Australia, respectively) are shown as solid gray lines.

term trends in $\log _{10} \mathrm{SO}_{4}$, with the notable exception of the Australian stratocumulus region (Figs. S3, 5, 6). This is probably because this region is dominated by biogenic sulfur produced by marine organisms (McCoy et al., 2015; Rap et al., 2013; Kloster et al., 2006; Ayers and Gras, 1991; Charlson et al., 1987; Meskhidze and Nenes, 2006). The MERRA2 reanalysis uses a climatology to inform it about fluxes of dimethyl sulfide (Randles et al., 2016) and it has very limited ability to simulate interannual variability. Note that correlations provided in Fig. 5 are between unsmoothed time series. The correlation between time series treated with a 365-day running mean are provided in Fig. 6 .

It is interesting to examine how well our predictions of the sensitivity of CDNC to $\mathrm{SO}_{4}$ based on daily variability extend to long-term trends. The coefficient linking $\log _{10}$ $\mathrm{SO}_{4}$ to $\log _{10} \mathrm{CDNC}$ inferred from $1^{\circ} \times 1^{\circ}$ daily data in the stratocumulus regions agrees with the relation between interannual variations in $\log _{10} \mathrm{SO}_{4}$ and $\log _{10} \mathrm{CDNC}$. This is shown in Fig. 6. The range of coefficients arrived at by training the regression model in the stratocumulus regions (Table 1) captures the coefficients linking interannual variations in $\log _{10} \mathrm{SO}_{4}$ to $\log _{10} \mathrm{CDNC}$ (Fig. 6). Most regions appear to be closer to the regression model trained in Australian stratocumulus, with the exception of the Hawaiian and Californian regions, which are closer to the regression model trained in Californian stratocumulus. It should be noted that 
the decadal trends in $\mathrm{CDNC}$ and $\mathrm{SO}_{4}$ shown in Fig. 5 are not driving the training of the regression model because the variance in $1^{\circ} \times 1^{\circ}$ daily mean CDNC exceeds the variance in regional mean CDNC by almost 3 orders of magnitude after the application of the 365-day moving average. Overall, it appears that the regression models trained in the stratocumulus regimes using daily data have the capability of predicting long-term variability in a variety of different regimes.

One interesting aspect of this analysis is that, while the time series of observed and predicted CDNC are well correlated (see Fig. 5 for correlation between unsmoothed time series and Fig. 6 for correlations between time series after the application of a 365-day running mean), uncertainty still exists in the sensitivity of $\mathrm{CDNC}$ to $\mathrm{SO}_{4}$ as characterized by the coefficient relating CDNC to $\mathrm{SO}_{4}$ in Eq. (1). It is unclear if this diversity is due to a real difference in the way that clouds and aerosol interact in these regions, perhaps due to differences in the effects of nucleation on CCN concentration (Gordon et al., 2016; Dunne et al., 2016), or if it is due to shortcomings in reanalysis or retrievals.

\section{Conclusions}

Several studies have shown that sulfate mass concentration influences CDNC (Boucher and Lohmann, 1995; Lowenthal et al., 2004; McCoy et al., 2017a, 2015; Storelvmo et al., 2009). Previous studies relating sulfate mass to remotely sensed CDNC were hampered by significant retrieval bias, making the interpretation of their results difficult (McCoy et al., 2017a). In this study we utilize daily mean data filtered on an individual retrieval basis to remove known sources of remote-sensing bias. The results agree with the relationship derived from monthly mean data in McCoy et al. (2017a). Based on this relationship, a first indirect radiative forcing of $-0.97 \mathrm{Wm}^{-2}$ was derived. The forcing found in McCoy et al. (2017a) based on the stratocumulus regions and confirmed globally by this study is stronger than found in previous empirical remote-sensing studies (Bellouin et al., 2013; Quaas et al., 2008), but not out of line with climate model studies forced to be consistent with in situ relationships between sulfate and CDNC (Storelvmo et al., 2009). Therefore remotely sensed CCN proxies that are not speciated are not as skillful a predictor of true $\mathrm{CCN}$ variability as sulfate mass and will underestimate the radiative forcing due to aerosol-cloud interactions.

In addition to showing the sensitivity of $\mathrm{CDNC}$ to $\mathrm{SO}_{4}$, we have shown that submicron sea spray as predicted by MERRA2 does not strongly affect CDNC except at very low sea spray mass. As noted above, the submicron sea spray in MERRA2 is effectively dependent on wind speed, so the precise coefficient relating sea salt to CDNC should change depending on the size distribution assumed by a different parameterization of sea spray emission, but should maintain the same qualitative dependence.
In summary, when remote-sensing retrieval biases are accounted for carefully, sulfate mass concentration near the surface covaries with observed CDNC in the same way in highly pristine and in polluted regions. Interannual variability in CDNC near passively degassing volcanoes agrees with both reanalysis $\mathrm{SO}_{4}$ and observed $\mathrm{SO}_{2}$. Further, the decadal trend in $\mathrm{CDNC}$ predicted by reanalysis aerosol in regions of maritime outflow near sources of intense anthropogenic pollution agrees with observed trends in CDNC. This shows that the relation between $\mathrm{CDNC}$ and $\mathrm{SO}_{4}$ has relevance to aerosol-cloud radiative forcing. To our knowledge this is the first study to use remote-sensing $\mathrm{SO}_{2}$ and $\mathrm{CDNC}$ to show that interannual variability in sulfur emissions alters CDNC. Based on this we suggest that the relation between sulfate mass and CDNC provides a constraint on aerosol-cloud interactions in GCMs.

Data availability. The MODIS data were obtained from NASA's Level 1 and Atmosphere Archive and Distribution System (LAADS) at https://ladsweb.modaps.eosdis.nasa.gov/. MERRA2 data were downloaded from the Giovanni data server.

Supplement. The supplement related to this article is available online at: https://doi.org/10.5194/acp-18-2035-2018-supplement.

Author contributions. DTM and FAMB planned the paper. DTM performed data analysis and calculations and wrote the text. DPG created the CDNC level-3 dataset from level-2 MODIS data. JKM downloaded and organized the MERRA2 aerosol data. All coauthors edited the paper, discussed results, and supported the analysis.

Competing interests. The authors declare that they have no conflict of interest.

Acknowledgements. Daniel T. McCoy and Paul R. Field acknowledge support from the PRIMAVERA project funded by the European Union's Horizon 2020 program under grant agreement no. 641727. The authors thank the editor and two anonymous reviewers for their insightful comments. Daniel P. Grosvenor was funded by both the University of Leeds under Paul Field and from the NERC-funded ACSIS programme via NCAS. Robert Wood would like to acknowledge support from NASA Award NNX16AP31G (CloudSat/CALIPSO Science Team Recompete). Dennis L. Hartmann was supported under NASA grant NNX14AG26G.

Edited by: Fangqun Yu

Reviewed by: two anonymous referees 


\section{References}

Albrecht, B. A.: Aerosols, Cloud Microphysics, and Fractional Cloudiness, Science, 245, 1227-1230, https://doi.org/10.1126/science.245.4923.1227, 1989.

Allen, G., Coe, H., Clarke, A., Bretherton, C., Wood, R., Abel, S. J., Barrett, P., Brown, P., George, R., Freitag, S., McNaughton, C., Howell, S., Shank, L., Kapustin, V., Brekhovskikh, V., Kleinman, L., Lee, Y.-N., Springston, S., Toniazzo, T., Krejci, R., Fochesatto, J., Shaw, G., Krecl, P., Brooks, B., McMeeking, G., Bower, K. N., Williams, P. I., Crosier, J., Crawford, I., Connolly, P., Allan, J. D., Covert, D., Bandy, A. R., Russell, L. M., Trembath, J., Bart, M., McQuaid, J. B., Wang, J., and Chand, D.: South East Pacific atmospheric composition and variability sampled along $20^{\circ} \mathrm{S}$ during VOCALS-REx, Atmos. Chem. Phys., 11, 5237-5262, https://doi.org/10.5194/acp-11-5237-2011, 2011.

Andreae, M. O., Jones, C. D., and Cox, P. M.: Strong present-day aerosol cooling implies a hot future, Nature, 435, 1187-1190, https://doi.org/10.1038/nature03671, 2005.

Ayers, G. P. and Gras, J. L.: Seasonal relationship between cloud condensation nuclei and aerosol methanesulphonate in marine air, Nature, 353, 834-835, 1991.

Bellouin, N., Quaas, J., Morcrette, J.-J., and Boucher, O.: Estimates of aerosol radiative forcing from the MACC re-analysis, Atmos. Chem. Phys., 13, 2045-2062, https://doi.org/10.5194/acp13-2045-2013, 2013.

Bennartz, R. and Rausch, J.: Global and regional estimates of warm cloud droplet number concentration based on 13 years of AQUA-MODIS observations, Atmos. Chem. Phys., 17, 98159836, https://doi.org/10.5194/acp-17-9815-2017, 2017.

Bennartz, R., Fan, J., Rausch, J., Leung, L. R., and Heidinger, A. K.: Pollution from China increases cloud droplet number, suppresses rain over the East China Sea, Geophys. Res. Lett., 38, https://doi.org/10.1029/2011GL047235, 2011.

Boucher, O. and Lohmann, U.: The sulfate-CCN-cloud albedo effect, Tellus B, 47, 281-300, https://doi.org/10.1034/j.16000889.47.issue3.1.x, 1995.

Boucher, O., Randall, D. A., Artaxo, P., Bretherton, C., Feingold, G., Forster, P. M., Kerminen, V.-M., Kondo, Y., Liao, H., Lohmann, U., Rasch, P., Satheesh, S. K., Sherwood, S. C., Stevens, B., and Zhang, X. Y.: Clouds and Aerosols Climate Change 2013 - The Physical Science Basis, Cambridge University Press, 571-657, 2014.

Bretherton, C. S., Wood, R., George, R. C., Leon, D., Allen, G., and Zheng, X.: Southeast Pacific stratocumulus clouds, precipitation and boundary layer structure sampled along $20^{\circ} \mathrm{S}$ during VOCALS-REx, Atmos. Chem. Phys., 10, 10639-10654, https://doi.org/10.5194/acp-10-10639-2010, 2010.

Buchard, V., da Silva, A. M., Colarco, P. R., Darmenov, A., Randles, C. A., Govindaraju, R., Torres, O., Campbell, J., and Spurr, R.: Using the OMI aerosol index and absorption aerosol optical depth to evaluate the NASA MERRA Aerosol Reanalysis, Atmos. Chem. Phys., 15, 5743-5760, https://doi.org/10.5194/acp15-5743-2015, 2015.

Carn, S. A., Fioletov, V. E., McLinden, C. A., Li, C., and Krotkov, N. A.: A decade of global volcanic SO2 emissions measured from space, Sci. Rep.-UK, 7, 44095, https://doi.org/10.1038/srep44095, 2017.

Charlson, R. J., Lovelock, J. E., Andreae, M. O., and Warren, S. G.: Oceanic phytoplankton, atmospheric sulfur, cloud albedo and cli- mate, Nature, 326, 655-661, https://doi.org/10.1038/326655a0, 1987.

Charlson, R. J., Schwartz, S. E., Hales, J. M., Cess, R. D., Coakley, J. A., Hansen, J. E., and Hofmann, D. J.: Climate Forcing by Anthropogenic Aerosols, Science, 255, 423-430, https://doi.org/10.1126/science.255.5043.423, 1992.

Christensen, M. W., Neubauer, D., Poulsen, C. A., Thomas, G. E., McGarragh, G. R., Povey, A. C., Proud, S. R., and Grainger, R. G.: Unveiling aerosol-cloud interactions - Part 1: Cloud contamination in satellite products enhances the aerosol indirect forcing estimate, Atmos. Chem. Phys., 17, 13151-13164, https://doi.org/10.5194/acp-17-13151-2017, 2017.

Dunne, E. M., Gordon, H., Kürten, A., Almeida, J., Duplissy, J., Williamson, C., Ortega, I. K., Pringle, K. J., Adamov, A., Baltensperger, U., Barmet, P., Benduhn, F., Bianchi, F., Breitenlechner, M., Clarke, A., Curtius, J., Dommen, J., Donahue, N. M., Ehrhart, S., Flagan, R. C., Franchin, A., Guida, R., Hakala, J., Hansel, A., Heinritzi, M., Jokinen, T., Kangasluoma, J., Kirkby, J., Kulmala, M., Kupc, A., Lawler, M. J., Lehtipalo, K., Makhmutov, V., Mann, G., Mathot, S., Merikanto, J., Miettinen, P., Nenes, A., Onnela, A., Rap, A., Reddington, C. L. S., Riccobono, F., Richards, N. A. D., Rissanen, M. P., Rondo, L., Sarnela, N., Schobesberger, S., Sengupta, K., Simon, M., Sipilä, M., Smith, J. N., Stozkhov, Y., Tomé, A., Tröstl, J., Wagner, P. E., Wimmer, D., Winkler, P. M., Worsnop, D. R., and Carslaw, K. S.: Global atmospheric particle formation from CERN CLOUD measurements, Science, 354, 1119-1124, https://doi.org/10.1126/science.aaf2649, 2016.

Elias, T. and Sutton, A. J.: Sulfur Dioxide Emission Rates from Kīlauea Volcano, Hawaii, an Update: 2002-2006: U.S. Geological Survey Open-File Report 2007-1114, 37 pp., 2007.

Forster, P. M.: Inference of climate sensitivity from analysis of Earth's energy budget, Annu. Rev. Earth Pl. Sc., 44, 85-106, 2016.

Gassó, S.: Satellite observations of the impact of weak volcanic activity on marine clouds, J. Geophys. Res.-Atmos., 113, D14S19, https://doi.org/10.1029/2007JD009106, 2008.

Ghan, S. J., Guzman, G., and Abdul-Razzak, H.: Competition between sea salt and sulfate particles as cloud condensation nuclei, J. Atmos. Sci., 55, 3340-3347, 1998.

Gong, S. L.: A parameterization of sea-salt aerosol source function for sub- and super-micron particles, Global Biogeochem. Cy., 17, 1097, https://doi.org/10.1029/2003GB002079, 2003.

Gordon, H., Sengupta, K., Rap, A., Duplissy, J., Frege, C., Williamson, C., Heinritzi, M., Simon, M., Yan, C., Almeida, J., Tröstl, J., Nieminen, T., Ortega, I. K., Wagner, R., Dunne, E. M., Adamov, A., Amorim, A., Bernhammer, A.-K., Bianchi, F., Breitenlechner, M., Brilke, S., Chen, X., Craven, J. S., Dias, A., Ehrhart, S., Fischer, L., Flagan, R. C., Franchin, A., Fuchs, C., Guida, R., Hakala, J., Hoyle, C. R., Jokinen, T., Junninen, H., Kangasluoma, J., Kim, J., Kirkby, J., Krapf, M., Kürten, A., Laaksonen, A., Lehtipalo, K., Makhmutov, V., Mathot, S., Molteni, U., Monks, S. A., Onnela, A., Peräkylä, O., Piel, F., Petäjä, T., Praplan, A. P., Pringle, K. J., Richards, N. A. D., Rissanen, M. P., Rondo, L., Sarnela, N., Schobesberger, S., Scott, C. E., Seinfeld, J. H., Sharma, S., Sipilä, M., Steiner, G., Stozhkov, Y., Stratmann, F., Tomé, A., Virtanen, A., Vogel, A. L., Wagner, A. C., Wagner, P. E., Weingartner, E., Wimmer, D., Winkler, P. M., Ye, P., Zhang, X., Hansel, A., Dom- 
men, J., Donahue, N. M., Worsnop, D. R., Baltensperger, U., Kulmala, M., Curtius, J., and Carslaw, K. S.: Reduced anthropogenic aerosol radiative forcing caused by biogenic new particle formation, P. Natl. Acad. Sci. USA, 113, 12053-12058, https://doi.org/10.1073/pnas.1602360113, 2016.

Grosvenor, D. P. and Wood, R.: The effect of solar zenith angle on MODIS cloud optical and microphysical retrievals within marine liquid water clouds, Atmos. Chem. Phys., 14, 7291-7321, https://doi.org/10.5194/acp-14-7291-2014, 2014.

Gryspeerdt, E., Quaas, J., and Bellouin, N.: Constraining the aerosol influence on cloud fraction, J. Geophys. Res.-Atmos., 121, 2015JD023744, https://doi.org/10.1002/2015JD023744, 2016.

Gryspeerdt, E., Quaas, J., Ferrachat, S., Gettelman, A., Ghan, S., Lohmann, U., Morrison, H., Neubauer, D., Partridge, D. G., Stier, P., Takemura, T., Wang, H., Wang, M., and Zhang, K.: Constraining the instantaneous aerosol influence on cloud albedo, P. Natl. Acad. Sci. USA, 114, 4899-4904, https://doi.org/10.1073/pnas.1617765114, 2017.

Hand, J. L., Schichtel, B. A., Malm, W. C., and Pitchford, M. L.: Particulate sulfate ion concentration and $\mathrm{SO}_{2}$ emission trends in the United States from the early 1990s through 2010, Atmos. Chem. Phys., 12, 10353-10365, https://doi.org/10.5194/acp-1210353-2012, 2012.

Hansen, J., Sato, M., and Ruedy, R.: Radiative forcing and climate response, J. Geophys. Res.-Atmos., 102, 6831-6864, https://doi.org/10.1029/96JD03436, 1997.

He, H., Vinnikov, K. Y., Li, C., Krotkov, N. A., Jongeward, A. R., Li, Z., Stehr, J. W., Hains, J. C., and Dickerson, R. R.: Response of $\mathrm{SO} 2$ and particulate air pollution to local and regional emission controls: A case study in Maryland, Earths Future, 4, 94-109, https://doi.org/10.1002/2015EF000330, 2016.

Hegg, D. A., Nielsen, K., Jonsson, H. H., Durkee, P. A., and Covert, D. S.: Factors influencing the mesoscale variations in marine stratocumulus albedo, Tellus, 59, 66-76, https://doi.org/10.1111/j.1600-0889.2006.00231.x, 2007.

Jaeglé, L., Quinn, P. K., Bates, T. S., Alexander, B., and Lin, J.-T.: Global distribution of sea salt aerosols: new constraints from in situ and remote sensing observations, Atmos. Chem. Phys., 11, 3137-3157, https://doi.org/10.5194/acp-11-3137-2011, 2011.

King, M. D., Menzel, W. P., Kaufman, Y. J., Tanre, D., BoCai, G., Platnick, S., Ackerman, S. A., Remer, L. A., Pincus, R., and Hubanks, P. A.: Cloud and aerosol properties, precipitable water, and profiles of temperature and water vapor from MODIS, IEEE T. Geosci. Remote, 41, 442-458, https://doi.org/10.1109/TGRS.2002.808226, 2003.

Kloster, S., Feichter, J., Maier-Reimer, E., Six, K. D., Stier, P., and Wetzel, P.: DMS cycle in the marine ocean-atmosphere system - a global model study, Biogeosciences, 3, 29-51, https://doi.org/10.5194/bg-3-29-2006, 2006.

Krotkov, N. A., Schoeberl, M. R., Morris, G. A., Carn, S., and Yang, K.: Dispersion and lifetime of the SO2 cloud from the August 2008 Kasatochi eruption, J. Geophys. Res.-Atmos., 115, D00L20, https://doi.org/10.1029/2010JD013984, 2010.

Krotkov, N. A., McLinden, C. A., Li, C., Lamsal, L. N., Celarier, E. A., Marchenko, S. V., Swartz, W. H., Bucsela, E. J., Joiner, J., Duncan, B. N., Boersma, K. F., Veefkind, J. P., Levelt, P. F., Fioletov, V. E., Dickerson, R. R., He, H., Lu, Z., and Streets, D. G.: Aura OMI observations of regional $\mathrm{SO}_{2}$ and $\mathrm{NO}_{2}$ pollu- tion changes from 2005 to 2015, Atmos. Chem. Phys., 16, 46054629, https://doi.org/10.5194/acp-16-4605-2016, 2016.

Lachlan-Cope, T., Listowski, C., and O'Shea, S.: The microphysics of clouds over the Antarctic Peninsula - Part 1: Observations, Atmos. Chem. Phys., 16, 15605-15617, https://doi.org/10.5194/acp-16-15605-2016, 2016.

Li, C., Zhang, Q., Krotkov, N. A., Streets, D. G., He, K., Tsay, S.-C., and Gleason, J. F.: Recent large reduction in sulfur dioxide emissions from Chinese power plants observed by the Ozone Monitoring Instrument, Geophys. Res. Lett., 37, L08807, https://doi.org/10.1029/2010GL042594, 2010.

Li, C., Joiner, J., Krotkov, N. A., and Bhartia, P. K.: A fast and sensitive new satellite $\mathrm{SO}_{2}$ retrieval algorithm based on principal component analysis: Application to the ozone monitoring instrument, Geophys. Res. Lett., 40, 6314-6318, https://doi.org/10.1002/2013GL058134, 2013.

Longo, B. M., Yang, W., Green, J. B., Crosby, F. L., and Crosby, V. L.: Acute Health Effects Associated with Exposure to Volcanic Air Pollution (vog) from Increased Activity at Kilauea Volcano in 2008, J. Toxicol. Env. Heal. A, 73, 1370-1381, https://doi.org/10.1080/15287394.2010.497440, 2010.

Lowenthal, D. H., Borys, R. D., Choularton, T. W., Bower, K. N., Flynn, M. J., and Gallagher, M. W.: Parameterization of the cloud droplet-sulfate relationship, Atmos. Environ., 38, 287-292, https://doi.org/10.1016/j.atmosenv.2003.09.046, 2004.

Lu, M.-L., Conant, W. C., Jonsson, H. H., Varutbangkul, V., Flagan, R. C., and Seinfeld, J. H.: The Marine Stratus/Stratocumulus Experiment (MASE): Aerosol-cloud relationships in marine stratocumulus, J. Geophys. Res.-Atmos., 112, D10209, https://doi.org/10.1029/2006JD007985, 2007.

Lu, Z., Zhang, Q., and Streets, D. G.: Sulfur dioxide and primary carbonaceous aerosol emissions in China and India, 1996-2010, Atmos. Chem. Phys., 11, 9839-9864, https://doi.org/10.5194/acp-11-9839-2011, 2011.

Ma, J., Chen, Y., Wang, W., Yan, P., Liu, H., Yang, S., Hu, Z., and Lelieveld, J.: Strong air pollution causes widespread hazeclouds over China, J. Geophys. Res.-Atmos., 115, D18204, https://doi.org/10.1029/2009JD013065, 2010.

Mace, G. G. and Abernathy, A. C.: Observational evidence for aerosol invigoration in shallow cumulus downstream of Mount Kilauea, Geophys. Res. Lett., 43, 2981-2988, https://doi.org/10.1002/2016GL067830, 2016.

Mace, G. G. and Avey, S.: Seasonal Variability of Warm Boundary Layer Cloud and Precipitation Properties in the Southern Ocean as Diagnosed from A-Train Data, J. Geophys. Res.-Atmos. 2016JD025348, https://doi.org/10.1002/2016JD025348, 2016.

Malavelle, F. F., Haywood, J. M., Jones, A., Gettelman, A., Clarisse, L., Bauduin, S., Allan, R. P., Karset, I. H. H., Kristjánsson, J. E., Oreopoulos, L., Cho, N., Lee, D., Bellouin, N., Boucher, O., Grosvenor, D. P., Carslaw, K. S., Dhomse, S., Mann, G. W., Schmidt, A., Coe, H., Hartley, M. E., Dalvi, M., Hill, A. A., Johnson, B. T., Johnson, C. E., Knight, J. R., O'Connor, F. M., Partridge, D. G., Stier, P., Myhre, G., Platnick, S., Stephens, G. L., Takahashi, H., and Thordarson, T.: Strong constraints on aerosol-cloud interactions from volcanic eruptions, Nature, 546, 485-491, https://doi.org/10.1038/nature22974, 2017.

Matsui, T., Masunaga, H., Kreidenweis, S. M., Pielke, R. A., Tao, W. K., Chin, M., and Kaufman, Y. J.: Satellite-based assessment of marine low cloud variability associated with aerosol, atmo- 
spheric stability, and the diurnal cycle, J. Geophys. Res.-Atmos., 111, D17204, https://doi.org/10.1029/2005jd006097, 2006.

McCoy, D. T. and Hartmann, D. L.: Observations of a substantial cloud-aerosol indirect effect during the 2014-2015 BárðarbungaVeiðivötn fissure eruption in Iceland, Geophys. Res. Lett., 42, 2015GL067070, https://doi.org/10.1002/2015GL067070, 2015.

McCoy, D. T., Burrows, S. M., Wood, R., Grosvenor, D. P., Elliott, S. M., Ma, P.-L., Rasch, P. J., and Hartmann, D. L.: Natural aerosols explain seasonal and spatial patterns of Southern Ocean cloud albedo, Science Advances, 1, e1500157, https://doi.org/10.1126/sciadv.1500157, 2015.

McCoy, D. T., Bender, F. A. M., Mohrmann, J. K. C., Hartmann, D. L., Wood, R., and Grosvenor, D. P.: The global aerosol-cloud first indirect effect estimated using MODIS, MERRA and AeroCom, J. Geophys. Res.-Atmos., 1779-1796, https://doi.org/10.1002/2016JD026141, 2017a.

McCoy, D. T., Field, P. R., Schmidt, A., Grosvenor, D. P., Bender, F. A.-M., Shipway, B. J., Hill, A. A., and Wilkinson, J. M.: The aerosol-cyclone indirect effect in observations and high-resolution simulations, Atmos. Chem. Phys. Discuss., https://doi.org/10.5194/acp-2017-649, in review, 2017 b.

Meskhidze, N. and Nenes, A.: Phytoplankton and Cloudiness in the Southern Ocean, Science, 314, 1419-1423, https://doi.org/10.1126/science.1131779, 2006.

Mijling, B., van der A, R. J., Boersma, K. F., Van Roozendael, M., De Smedt, I., and Kelder, H. M.: Reductions of NO2 detected from space during the 2008 Beijing Olympic Games, Geophys. Res. Lett., 36, L13801, https://doi.org/10.1029/2009GL038943, 2009

Nakajima, T. and King, M. D.: Determination of the optical thickness and effective particle radius of clouds from reflected solar radiation measurements. Part I: Theory, J. Atmos. Sci., 47, 1878$1893,1990$.

Nakajima, T., Higurashi, A., Kawamoto, K., and Penner, J. E.: A possible correlation between satellite-derived cloud and aerosol microphysical parameters, Geophys. Res. Lett., 28, 1171-1174, https://doi.org/10.1029/2000GL012186, 2001.

Painemal, D. and Zuidema, P.: Assessment of MODIS cloud effective radius and optical thickness retrievals over the Southeast Pacific with VOCALS-REx in situ measurements, J. Geophys. Res.-Atmos., 116, D24206, https://doi.org/10.1029/2011jd016155, 2011

Patel, P. N., Quaas, J., and Kumar, R.: A new statistical approach to improve the satellite-based estimation of the radiative forcing by aerosol-cloud interactions, Atmos. Chem. Phys., 17, 3687-3698, https://doi.org/10.5194/acp-17-3687-2017, 2017.

Quaas, J., Boucher, O., Bellouin, N., and Kinne, S.: Satellitebased estimate of the direct and indirect aerosol climate forcing, J. Geophys. Res.-Atmos., 113, D05204, https://doi.org/10.1029/2007JD008962, 2008.

Quaas, J., Ming, Y., Menon, S., Takemura, T., Wang, M., Penner, J. E., Gettelman, A., Lohmann, U., Bellouin, N., Boucher, O., Sayer, A. M., Thomas, G. E., McComiskey, A., Feingold, G., Hoose, C., Kristjánsson, J. E., Liu, X., Balkanski, Y., Donner, L. J., Ginoux, P. A., Stier, P., Grandey, B., Feichter, J., Sednev, I., Bauer, S. E., Koch, D., Grainger, R. G., Kirkevåg, A., Iversen, T., Seland, Ø., Easter, R., Ghan, S. J., Rasch, P. J., Morrison, H., Lamarque, J.-F., Iacono, M. J., Kinne, S., and Schulz, M.: Aerosol indirect effects - general circulation model intercom- parison and evaluation with satellite data, Atmos. Chem. Phys., 9, 8697-8717, https://doi.org/10.5194/acp-9-8697-2009, 2009.

Ramanathan, V., Crutzen, P. J., Lelieveld, J., Mitra, A. P., Althausen, D., Anderson, J., Andreae, M. O., Cantrell, W., Cass, G. R., Chung, C. E., Clarke, A. D., Coakley, J. A., Collins, W. D., Conant, W. C., Dulac, F., Heintzenberg, J., Heymsfield, A. J., Holben, B., Howell, S., Hudson, J., Jayaraman, A., Kiehl, J. T., Krishnamurti, T. N., Lubin, D., McFarquhar, G., Novakov, T., Ogren, J. A., Podgorny, I. A., Prather, K., Priestley, K., Prospero, J. M., Quinn, P. K., Rajeev, K., Rasch, P., Rupert, S., Sadourny, R., Satheesh, S. K., Shaw, G. E., Sheridan, P., and Valero, F. P. J.: Indian Ocean Experiment: An integrated analysis of the climate forcing and effects of the great Indo-Asian haze, J. Geophys. Res.-Atmos., 106, 28371-28398, https://doi.org/10.1029/2001JD900133, 2001.

Randles, C. A., da Silva, A. M., Buchard, V., Darmenov, A., Colarco, P. R., Aquila, V., Bian, H., Nowottnick, E. P., Pan, X., Smirnov, A., Yu, H., and Govindaraju, R.: The MERRA-2 Aerosol Assimilation, Technical Report Series on Global Modeling and Data Assimilation, 45, 1-140, 2016.

Rap, A., Scott, C. E., Spracklen, D. V., Bellouin, N., Forster, P. M., Carslaw, K. S., Schmidt, A., and Mann, G.: Natural aerosol direct and indirect radiative effects, Geophys. Res. Lett., 40, 3297 3301, https://doi.org/10.1002/grl.50441, 2013.

Reddington, C., Carslaw, K., Stier, P., Schutgens, N., Coe, H., Liu, D., Allan, J., Pringle, K., Lee, L., and Yoshioka, M.: The Global Aerosol Synthesis and Science Project (GASSP): measurements and modelling to reduce uncertainty, B. Am. Meteorol. Soc., 98.9, 1857-1877, 2017.

Rienecker, M. M., Suarez, M. J., Gelaro, R., Todling, R., Julio Bacmeister, Liu, E., Bosilovich, M. G., Schubert, S. D., Takacs, L., Kim, G.-K., Bloom, S., Chen, J., Collins, D., Conaty, A., Silva, A. d., Gu, W., Joiner, J., Koster, R. D., Lucchesi, R., Molod, A., Owens, T., Pawson, S., Pegion, P., Redder, C. R., Reichle, R., Robertson, F. R., Ruddick, A. G., Sienkiewicz, M., and Woollen, J.: MERRA: NASA's Modern-Era Retrospective Analysis for Research and Applications, J. Climate, 24, 3624-3648, https://doi.org/10.1175/JCLI-D-11-00015.1, 2011.

Schmidt, A., Carslaw, K. S., Mann, G. W., Rap, A., Pringle, K. J., Spracklen, D. V., Wilson, M., and Forster, P. M.: Importance of tropospheric volcanic aerosol for indirect radiative forcing of climate, Atmos. Chem. Phys., 12, 7321-7339, https://doi.org/10.5194/acp-12-7321-2012, 2012.

Sekiguchi, M., Nakajima, T., Suzuki, K., Kawamoto, K., Higurashi, A., Rosenfeld, D., Sano, I., and Mukai, S.: A study of the direct and indirect effects of aerosols using global satellite data sets of aerosol and cloud parameters, J. Geophys. Res.-Atmos., 108, 4699, https://doi.org/10.1029/2002JD003359, 2003.

Storelvmo, T., Lohmann, U., and Bennartz, R.: What governs the spread in shortwave forcings in the transient IPCC AR4 models?, Geophys. Res. Lett., 36, L01806 https://doi.org/10.1029/2008gl036069, 2009.

Tian, H., Qiu, P., Cheng, K., Gao, J., Lu, L., Liu, K., and Liu, X.: Current status and future trends of $\mathrm{SO} 2$ and $\mathrm{NOx}$ pollution during the 12th FYP period in Guiyang city of China, Atmos. Environ., 69, 273-280, https://doi.org/10.1016/j.atmosenv.2012.12.033, 2013. 
Twomey, S.: Influence of pollution on shortwave albedo of clouds, J. Atmos. Sci., 34, 1149-1152, https://doi.org/10.1175/15200469(1977)034<1149:tiopot>2.0.co; 2, 1977.

Wang, S., Zhang, Q., Randall, V. M., Sajeev, P., Fei, L., Meng, L., Xujia, J., and Kebin, H.: Satellite measurements oversee China's sulfur dioxide emission reductions from coalfired power plants, Environ. Res. Lett., 10, 114015-=-114024, https://doi.org/10.1088/1748-9326/10/11/114015, 2015.

Witte, J. C., Schoeberl, M. R., Douglass, A. R., Gleason, J. F., Krotkov, N. A., Gille, J. C., Pickering, K. E., and Livesey, N.: Satellite observations of changes in air quality during the 2008 Beijing Olympics and Paralympics, Geophys. Res. Lett., 36, L17803, https://doi.org/10.1029/2009GL039236, 2009.

Yuan, T., Remer, L. A., and Yu, H.: Microphysical, macrophysical and radiative signatures of volcanic aerosols in trade wind cumulus observed by the A-Train, Atmos. Chem. Phys., 11, 71197132, https://doi.org/10.5194/acp-11-7119-2011, 2011
Zhang, Z., Ackerman, A. S., Feingold, G., Platnick, S., Pincus, R., and Xue, H. W.: Effects of cloud horizontal inhomogeneity and drizzle on remote sensing of cloud droplet effective radius: Case studies based on large-eddy simulations, J. Geophys. Res.Atmos., 117, D19208, https://doi.org/10.1029/2012jd017655, 2012.

Zhao, B., Wang, S., Wang, J., Fu, J. S., Liu, T., Xu, J., Fu, X., and Hao, J.: Impact of national NOx and SO2 control policies on particulate matter pollution in China, Atmos. Environ., 77, 453463, https://doi.org/10.1016/j.atmosenv.2013.05.012, 2013. 